\title{
The Primary Exploration of the Human-Land Relationships in Dong Xiang County of Sichuan in the Mid-Qing Dynasty
}

\author{
Meng Wang \\ School of Politics and Law, Sichuan University of Arts and Science, Dazhou, China \\ Email:312142477@qq.com
}

How to cite this paper: Wang, M. (2019). The Primary Exploration of the $\mathrm{Hu}$ man-Land Relationships in Dong Xiang County of Sichuan in the Mid-Qing Dynasty. Advances in Historical Studies, 8, 107-113.

https://doi.org/10.4236/ahs.2019.82008

Received: February 21, 2019

Accepted: March 25, 2019

Published: March 28, 2019

Copyright $\odot 2019$ by author(s) and Scientific Research Publishing Inc. This work is licensed under the Creative Commons Attribution International License (CC BY 4.0).

http://creativecommons.org/licenses/by/4.0/

\begin{abstract}
There are many causes for white lotus rebellion occurred in Dong Xiang county in Sichuan province in the mid-Qing Dynasty. For example, more people and less land, low average yield and lack of effective measures to withstand natural disasters. Though the royal government exempted the taxes and duties many times, the lower class still lived with hardship. The contradictions between the officials and the people were intensified by the greedy local officials' blackmail, and as a result, the rebellion leaded by Wang San-Huai broke out.
\end{abstract}

\section{Keywords}

The Mid-Qing Dynasty, Sichuan, Dong Xiang County, The Human-Land Relationships

\section{Introduction}

In the late Ming and early Qing dynasties, a series of wars broke out in Sichuan province, followed by natural disasters and pestilence. As a result, the population of Sichuan has been drastically reduced. The tragic war at that time left an indelible memory for the present and future generations. Many historical records and local chronicles contain relevant descriptions. "Three or four out of ten people died of Zhang Xianzhong's massacre in southern Sichuan; two or three out of ten died of plague and tigers, while only less than one percent of the population was alive. In the late Ming and early Qing, Sichuan suffered a variety of disasters, such as war, plague, tiger suffering and so on, which made a dramatic reduction in population. For the lucky few people, there's the chance of survival in so many disasters. Two-thirds of the people died in Zhang Xianzhong's mas- 
sacre in eastern Sichuan; four-tenths and five-tenths died in the Yaohuang Army; two-tenths and three-tenths died in plague and tigers; while less than one over ten thousand of the total population lived before." (Pang et al., 1976). According to the estimates of scholars, the total population of Sichuan in the sixth year of Wanli in the Ming dynasty (1578) was more than 3,102,073 and in the early Qing dynasty, after many natural and man-made disasters, the population of Sichuan still remained about 500,000 according to the most conservative estimate (Li, 1987). Of course, there must be some difference between the actual population and the paper data. However, in the late Ming and early Qing Dynasties, the rapid decline in population and dramas caused by the long-term war in Sichuan were true, and created a special situation of a large population and a few land. Therefore, the government of the early Qing dynasty organized and implemented the large-scale migration measures of "the migration from Hunan and Guangdong to Sichuan province", which lasted for more than 60 years. By the middle of the Qing dynasty, the situation of such a large population and a few land no longer existed. The man-land relationship has become increasingly acute, which led to a series of social contradictions. This also became an important inducement for the White Lotus Society broke out in Sichuan, Shaanxi and Five Provinces during the period of Qian Long and Jia Qing.

\section{Discussion}

Given that human population explosion and the exploitation of forests began in the 18th century (Ho, 1959). In addition, constructs an indicator for whether a province was considered to be developed or not during the period (Wang, 2014) The Qing provinces are divided into three groups: developed, developing and undeveloped; population pressure in the developed provinces forced people to settle in hitherto unexplored lands, with the migration movement occurring from east to west. "Dongxiang county, the core area of Bailian sect in northeast Sichuan, In the seventh year of Yong Zheng (1729), the population of the county was only 28,800 at that time. In the first year of Jia Qing (1796), the population of the county had reached 18,900 households with 78,422 people. In the tenth year of Jia Qing (1806), the number increased to 105,865. In the sixteenth year of Jia Qing (1811), the county magistrate Xu Chen mo registered permanent residence. The number of Tax-paying farmers increased to 47,651 with a total of 208,754 men and women. If we add those who live in other places, tenants, businessmen and shops, the total number of households in the county reaches 50,872 totaling 220,118" (Xuanhan County Chronicle Compilation Committee of Sichuan Province, 1994). According to the relevant historical records, in the seventeen years of Jia Qing, Dongxiang County had 2,458 hectares and $84 \mathrm{mu}$ of upper, middle and lower fields ((Qing Dynasty) Chang et al. General records of Sichuan, 1967). This figure is consistent with the records in "Dongxiang county annals" compiled by Xu Chen mu ((Qing Dynasty) Xu, Dongxiang county annals, 1821). If we only count farmers who pay taxes, Dongxiang County has cultivated only 1.2 mu per capita in about 17 years of Jia Qing, which is one mu less 
than the average of Sichuan Province $(2.2 \mathrm{mu})$. However, the actual number of farmland areas per person in Dongxiang County may be more than $1.2 \mathrm{mu}$. Why do you say that? Although the historian cannot, like the sociologist, specify his data by designing elaborate questionnaires and by carrying out field surveys ( $\mathrm{Ho}$, 1964). Because in the early years of Qing Dynasty, in order to encourage immigrants to come to Sichuan to reclaim land, the Qing government formulated a relatively relaxed policy of reclaiming land and collecting money and grain per mu. "Qianlong five-year decree: Sichuan is located in the border, with more mountains and fewer fields. The land tax is divided into upper, middle and lower levels, and grain is levied according to grade. For example, if the measurement of upper and middle is less than half an mu, upper and middle are less than one $\mathrm{mu}$, and the barren land of hilltops, corners and stony sands between hectares are exempted from tax. In the twelve years of Daoguang, it was agreed that all the scattered land in the interior and border provinces should be reclaimed by the people and never be taxed. The number of exemptions, ... Sichuan Province, upper, middle and less than half an mu, upper, middle to less than one mu as a break. As for the inferior land in Henan and Sichuan... No matter the hectare or $\mathrm{mu}$, the tax shall be exempted" (Lu, 1984).

Of course, the Qing government's policy of benefiting the people was undoubtedly well motivated. And if implemented, the unregistered reclaimed wasteland, such as edges and corners, barren land and so on, will not be enough to pay taxes per mu of land, which will undoubtedly increase the per capita arable land occupancy of Dongxiang County and even Sichuan Province. However, in the traditional China of rule by man, good policies do not necessarily mean good results. Take the policy of the Qing Dynasty as an example. In the actual implementation process of the local government, there will be some problems in all aspects for their own self-interest, which inevitably leads to irregularities for favoritism.

Huang Fuchen has such a passage in his book Yingtian Collection, which is more thorough. "Land reclaimed must not be cleaned up unless there is an accident. The foolish people are easy to be confused. When they first hear about it, they should carefully measure the land. They are already in panic. When they see officials, they are especially afraid. Some bad bureaucrats took the opportunity to intimidate blackmail and put forward the idea of raising taxes. When the land is re-measured, the government will write the size of the land at will and the area of the bribery-givers will be smaller. In addition, there are people who are cunning in the countryside, colluding with government officials, apportioning the names of horses, wine, food, books and paper, and demanding according to the needs of each $\mathrm{mu}$, so as to satisfy their own pockets. Ten days before the land was measured, government officials gathered the villagers, waiting time was not clearly informed, so that they wasted the time of cultivation; even if they had a clear sense of personnel, the villagers had been deeply affected" (Lu, 1984). After all, pao-chia and li-chia that grouped civilians into hierarchically arranged decimal units for purposes of police control or tax collection (Kuhn, 1980). 
These malpractices exposed in land measurement, combined with corruption of officials throughout the country in the mid-Qing Dynasty, are by no means isolated cases. If there are also some local officials who are eager to make some achievements in office in order to get promotion and reward, then there will be more and more fraudulent practices such as less land reclamation and more tax increase. In addition, the population statistics of Dongxiang county are not very accurate. Compared with the actual population, it is inevitable to make mistakes. Therefore, in the seventeen years of Jia Qing, the per capita cultivated land in Dongxiang County was $1.2 \mathrm{mu}$, which may be deviated from the actual figure, but under the influence of various factors, the difference should not be too extraordinary.

In this way, the total arable land area of Dongxiang County in the mid-Qing Dynasty was not much, and the per capita arable land area was lower than the average level of Sichuan Province. What about the composition of land quality? Objectively speaking, the landform of northeastern Sichuan determines that it is destined to be more difficult in land reclamation and agricultural cultivation than in the plain area of Western Sichuan. The arable land, especially the fertile land, is more rare and precious. Dongxiang County, located in northeastern Sichuan Province, is dominated by low mountains and middle mountains. The area of low mountains and middle mountains accounts for $90.2 \%$ of the total area, and the average altitude of the county is about 800 meters (Xuanhan County Chronicle Compilation Committee of Sichuan Province, 1994). Jia Qing also has such a description, "Dongxiang County, there are endless mountains, mountains are high and steep, of which less than one tenth of the fields, and rocky mountains, can cultivate very little land."

In order to survive, the local people have to seek farmland from mountains and destroy forests for land. "In the mountains, farmland has been reclaimed layer by layer, some of which have reached more than 100 hectares, but the people do not know how to store water, resulting in drought. Only the plaster fields near the rivers are the real areas for rice production." In order to get a better harvest, adequate and convenient water resources are very important for farmland in Hilly areas, especially for rice cultivation. The high-yielding areas of crops in Dongxiang County are mainly distributed on the first and second terraces along the banks of the front, middle and back rivers which is Zhou rivers and Shuangxi river with abundant sunshine, flat terrain, good water resources and fertile land. In the future, Wangsanhuai, the leader of the Bailian uprising in Dongxiang, whose family is located in Lianchigou, is obviously not a fertile land. Because Dongxiang County had not much arable land and most of it was barren land, the Qing Dynasty implemented a policy of light corvee and slice taxes in Sichuan Province in order to cultivate people's livelihood. As a result, "Dongyi's taxation is not comparable to the number of townships in adjacent provinces, a total of 34,522 taxable, including 471 two additional taxes" ((Qing Dynasty) Xu, Dongxiang county annals, 1821). Generally speaking, the collection of grain and silver in the imperial court was not very large, and it was sometimes exempted. 
According to Jia Qing in Dongxiang county annals, in the twenty-five years, thirty-two years, forty-two years and forty-nine years of Kangxi, four exemptions were granted for money and grain, and one exemption was granted in Yongzheng seven years, even in the sixty years of Qianlong (1795) before the Wang Sanhuai Uprising. Emperor Qianlong said that the tax under heaven would be exempted, and the additional tax would remain for the public use of the province and be collected together next year. Sichuan Province was evenly divided into three years of exemption, Dazhou and its Dongxiang were listed as the second time, in Jia Qing two years of exemption. Nevertheless, the imperial court's exemption is one thing. Whether the local grass-roots government can execute meticulously without discount will be a big question mark. Moreover, the county's financial revenue is not much, which does not mean that the expenditure is also small. The salaries of the principal officials such as county magistrate of Dongxiang and the maintenance of honest and clean silver should be withheld and withdrawn from the grain and silver payments here.

In addition, the county Yamen have to support many long followers, private secretaries, Private advisers, government runners, personal servants, post-mortenm examiners, horsekeepers and so on by themselves. Even for the two sacrifices in the Spring and Autumn Period, the cost of food for prisoners and the rations for the poor and orphaned personnel should be drawn from the county finance (equivalent to the personal income of the county, a public-private account). Therefore, the seemingly legitimate income, usually even the county's normal annual branch cannot be maintained. Because of the financial management of the state and county in the Qing dynasty, the state and county officials were in fact in charge of all the financial management. Therefore, the fiscal deficit needs to be solved by the county itself. Moreover, Emperor Jia Qing had just inherited the throne, and the luxury and pleasure created by Emperor Qianlong had not been stopped. Under the effect of both upstream and downstream, corruption is rampant, and the local fiscal deficit is even more serious. Therefore, increasing tax revenue and extortion privately became a common problem of local grassroots regimes after the mid-Qing Dynasty, and became more and more intense. Cunning officials have also become a major stubborn disease in the administration of officials, Dongxiang County is no exception. All these magnify the contradiction between human and land resources invisibly. Susan Naquin and Evelyn S. Rawski's book draws on the most recent research to provide a unique overview and reevaluation of the social history of China during this period, one of the most dynamic periods in China's early modern era (Susan, 1989).

\section{Conclusion}

To sum up, in Dongxiang County of Sichuan Province in the mid-Qing Dynasty, if the bottom people only depended on land for their livelihood, it would be good to mix food and clothing in ordinary years. In the face of natural disasters and man-made disasters, people often face the situation of inadequate food. It is very difficult for ordinary people to achieve a well-off life, that is, a middle-level 
life (according to Hong Liangji's estimate, the minimum per capita land is 10 $\mathrm{mu}$ ). In the period of Qian Long and Jia Qing, when the total population had far exceeded the carrying capacity of land resources at that time, a large number of surplus agricultural labors should flow to the industrial and commercial sectors. However, due to the strict industrial and commercial control policies of the Qing government, a large number of land-less refugees were created. Eventually, this buried a huge hidden danger that triggered the Bailian uprising in Sichuan and Shaanxi provinces. They were not organized and did not seek to be in control of their destiny (Hsiao, 1968). Although the East Asian hinterlands boomed after 1750 , both in population and in manufacturing, this growth prevented these peripheral regions from exporting vital resources to the cloth-producing Yangzi Delta. As a result, growth in the core of East Asia's economy essentially stopped, and what growth did exist was forced along labor-intensive, resource-saving paths. Europe could have been forced down, too, had it not been for favorable resource stocks from underground and overseas (Pomeranz, 2001). It was manifested in Dongxiang County, where Wang Sanhuai and others rebelled. And, Barend J. ter Haar's text draws in a variety of primary sources, including histories, gazetteers, canonical records, memorials and essays, as well as secondary studies in Chinese, Japanese, English and French, in order to examine the White Lotus teachings in Chinese religious history (ter Haar, 1997). It's very helpful to know about the rebellion.

\section{Conflicts of Interest}

The authors declare no conflicts of interest regarding the publication of this paper.

\section{References}

Chang, M., Yang, F. et al. (1967). General Records of Sichuan (Vol. 63, p. 26). Taipei: Jinghua Press.

Ho, P. (1959). Studies on the Population of China, 1368-1953. Cambridge, MA: Harvard University Press.

Ho, P. (1964). The Ladder of Success in Late Imperial China: Aspects of Social Mobility, 1368-1911. New York: Columbia University Press.

Hsiao, K.-C (1968). Rural China: Imperial Control in the Nineteenth Century (p. 264). Seattle: University of Washington Press.

Kenneth, P. (2001). The Great Divergence. Princeton, NJ: Princeton University Press.

Kuhn, P. A. (1980). Rebellion and Its Enemies in Late Imperial China (p. 24). Cambridge, MA: Harvard University Press.

Li, S. P. (1987). Population History of Sichuan (pp. 146-155). Chengdu: Sichuan University Press.

Lu, Z. J. (1984). Financial Historical Materials of Sichuan in Qing Dynasty (Volume 1, (pp. 63, 98). Chengdu: Press of Sichuan Academy of Social Sciences.

Pang, L., Wang, C. et al. (1976). Annals of Xuanhan County, Sichuan (Six Volumes, p. 1371). Taipei: Cheng Wen Publishing. 
Susan, N. (1989). Chinese Society in the Eighteenth Century. New Haven, CT: Yale University Press.

ter Haar, B. J. (1997). The White Lotus Teachings in Chinese Religious History. Brill Academic Pub.

Wang, Y.-C. (2014). Land Taxation in Imperial China, 1750-1911. Cambridge, MA: Harvard University Press.

Xu, C. M. (1821). Dongxiang County Annals (8 Volumes).

Xuanhan County Chronicle Compilation Committee of Sichuan Province (1994). Xuanhan County Annals (pp. 107-118). Chengdu: Southwest University of Finance and Economics Press. 